\title{
Naphthaleneacetic Acid, Ethephon, and Gibberellin A4 + A7 Have Variable Effects on Flesh Firmness and Return Bloom of Apple
}

\author{
Steven McArtney ${ }^{1,2,3}$, Dick Unrath ${ }^{1}$, J.D. Obermiller ${ }^{1}$, and \\ Ann Green ${ }^{4}$
}

AdDitional INDEX wORDs. Malus $\times$ domestica, bioregulator, biennial bearing, floral spurs, NAA, Ethrel, $\mathrm{GA}_{4+7}$

SUMMARY. Experiments were conducted in commercial apple (Malus $\times$ domestica) orchards in the southeastern U.S. between 1998 and 2006 with the primary objective of evaluating the effects of naphthaleneacetic acid (NAA) and ethephon on return bloom. NAA increased return bloom in six of 10 experiments, whereas ethephon increased return bloom in four of seven experiments. Four biweekly applications of 5 ppm NAA during June and July (early summer NAA) increased return bloom more consistently than fewer applications. Four weekly preharvest applications of $5 \mathrm{ppm}$ NAA increased return bloom of 'Delicious' and 'Golden Delicious' as effectively as early summer applications. Combining NAA and ethephon in early summer sprays did not consistently increase return bloom compared with either material alone. The flower cluster density of 'Golden Delicious' in the year of treatment had a negative effect on return bloom that was more pronounced on control trees than trees sprayed 5 weeks after bloom with 444 ppm ethephon (48 fl oz/acre Ethrel). Combining four early summer sprays of 316 ppm ethephon (24 fl oz/acre Ethrel) with 15 ppm gibberellin A4 + A7 (GA $4+7)$ increased return bloom of 'Cameo' but had no effect on return bloom of 'Mutsu' or 'Golden Delicious'. Growth regulator treatments did not have a consistent effect on fruit firmness in the year of treatment. Naphthaleneacetic acid or ethephon treatments in the on year of a biennial bearing cycle can promote return bloom of apple spurs. However, the positive effect on return bloom may be minimal in cultivars with a strong natural tendency toward biennial bearing or when bloom or initial fruit set are heavy in the year of treatment.

$\mathrm{M}$ any apple cultivars, including 'Golden Delicious', 'Fuji', 'Cameo', 'Pacific Rose', 'York Imperial', 'Braeburn', and 'Mutsu', are prone to develop a biennial bearing habit: a repeating cycle of heavy and light blooming/cropping years. Biennial bearing can have pronounced negative economic consequences resulting from its effect on orchard productivity and fruit quality. Cumulative yields of apple cultivars

Mention of a trademark, proprietary product, or vendor does not constitute a guarantee or warranty of the product and does not imply its approval to the exclusion of other products or vendors that may also be suitable.

We express our appreciation to AMVAC Chemical Corporation and Fine Americas Limited for their gift of chemicals

${ }^{1}$ Department of Horticultural Science, North Carolina State University, Mountain Horticultural Crops Research and Extension Center, 455 Research Drive, Fletcher, NC 28732

${ }^{2}$ Southeast Apple Specialist (North Carolina, South Carolina, Georgia, Tennessee).

${ }^{3}$ Corresponding author. E-mail: steve_mcartney@ncsu.edu

${ }^{4}$ Department of Horticultural Science, North Carolina State University, 120 Kilgore Hall/Campus Box 7609, Raleigh, NC 27695-7609 that exhibit a biennial bearing habit are less than the cumulative yields of cultivars that bear regularly (Jonkers, 1979). Fruit from light-cropping trees can develop a higher incidence of the calcium-related storage disorder bitter pit (Ferguson and Watkins, 1992). A successful chemical thinning program will normally result in adequate return bloom and consistent cropping. Williams (1979) attributed the increased consistency of U.S. apple production after 1949 to the widespread commercial adoption of chemical thinning technology from that year. However, cultivars that exhibit a strong tendency to biennial bear may not produce sufficient bloom to guarantee a return crop even when a postbloom chemical thinning treatment has successfully reduced crop load the previous year (Ferree and Schmid, 2000; Guak et al., 2004; Meland, 1998; Reginato et al., 2001).

Restoring trees from a biennial bearing habit to more consistent cropping may be achieved by regulating the flower formation process to create a more equal balance between flowering and vegetative (resting) spurs. Inhibition of flower bud formation of some spurs in the light cropping year when most or all spurs would otherwise be initiating and differentiating a flower cluster, or promotion of flower bud formation in the heavy cropping year when most spurs would otherwise remain vegetative, could result in more consistent cropping. Various gibberellins can inhibit flower bud formation in apple (Bertelsen and Tustin, 2002; Dennis and Edgerton, 1966; Li et al., 1995; Marino and Greene, 1981; McArtney, 1994; McArtney and Li, 1998; Meador and Taylor, 1987; Tromp, 1973, 1982). Application of $\mathrm{GA}_{3}$ or $\mathrm{GA}_{7}$ in the off year of a biennial bearing cycle inhibited flower bud formation of 'Braeburn', resulting in a more equal balance between vegetative and floral spurs in each of the 2 years after treatment (McArtney, 1994). However, application of GAs in the light cropping year of a biennial bearing cycle has not been adopted in commercial practice because of the high cost per acre at the rates of GA required for efficacy. Various growth regulators have been shown to promote flower bud formation in apple. Harley et al. (1958) reported that flowering in apple was increased by NAA to a greater extent than could be accounted for by fruit removal alone, providing direct evidence that NAA stimulated flower bud formation independently of crop load. Postbloom applications of ethephon increased return bloom in 'Wellspur Delicious'

\begin{tabular}{llll}
\hline $\begin{array}{l}\text { Unit } \\
\begin{array}{l}\text { To convert U.S. to SI, } \\
\text { multiply by }\end{array}\end{array}$ & U.S unit & SI unit & $\begin{array}{l}\text { To convert SI to U.S., } \\
\text { multiply by }\end{array}$ \\
\hline 0.0731 & fl oz/acre & $\mathrm{L} \cdot \mathrm{ha}^{-1}$ & 13.6840 \\
9.3540 & gal/acre & $\mathrm{L} \cdot \mathrm{ha}^{-1}$ & 0.1069 \\
25.4 & inch(es) & $\mathrm{mm}$ & 0.0394 \\
6.4516 & inch & $\mathrm{cm}^{2}$ & 0.1550 \\
4.4482 & lbf & $\mathrm{N}$ & 0.2248 \\
1 & ppm & $\mathrm{mg} \cdot \mathrm{L}^{-1}$ & 1
\end{tabular}


apple trees without reducing fruit set (Williams, 1972). Application of $\mathrm{GA}_{4}$ to 'Golden Delicious' in the heavy cropping year of a biennial bearing cycle increased the proportion of spurs that produced a flower in the next year (Looney et al., 1985).

There have been various webbased recommendations for NAA or ethephon treatments to promote return bloom of apple (Schwallier, 2006; UMass Fruit Team, 2001, 2002 ) but no publications that directly compare the efficacy of these two growth regulators. The primary objective of this research was to evaluate the potential for NAA or ethephon application(s) in the heavy cropping year of a biennial bearing cycle to promote return bloom of apple under commercial conditions in the southeastern U.S. Lesser objectives of the work were to l) evaluate their effects on fruit firmness in the year of treatment; 2) compare the efficacy of early summer, preharvest, and postharvest NAA sprays; 3 ) determine how the level of bloom in the year of treatment influences the return bloom response to ethephon; and 4) evaluate the effects of combining $\mathrm{GA}_{4+7}$ with ethephon.

\section{Materials and methods}

NAA FREQUENCY, 1998-1999. Replicated field trials were undertaken at three commercial orchards in Henderson County, N.C., to determine the effect of number of NAA applications during early summer on return bloom. The cultivars and rootstocks used were 'Delicious' /M.7 (M.7), 'Smoothee Golden Delicious' /M.7, and 'Golden Delicious' / M.7. The date of full bloom on each orchard was $\approx 15$ Apr. NAA (Fruitone $\mathrm{N}$; Amvac Chemical Corp., Newport Beach, Calif.) was applied 0, 1, 2, 3, or 4 times at biweekly intervals beginning on 7 June at a concentration of $5 \mathrm{ppm}$. Treatments were applied with an airblast sprayer calibrated to deliver $80 \%$ of the calculated tree row volume (TRV) in each orchard. Two additional treatments were included in the 'Delicious' study: four weekly applications of 5 ppm NAA during the month before harvest ("preharvest NAA") intended as a stop drop treatment and a combined early summer plus preharvest NAA treatment (eight NAA applications in total). Treatments were applied to single tree plots arranged in randomized complete block design experiments with four replications. Flesh firmness was measured with a penetrometer fitted with an 11.1-mm tip (Effegi, Alfonsine, Italy) on opposite pared sides of 20 randomly selected fruit per plot sampled during the commercial harvest period for the 'Golden Delicious' and 'Smoothee Golden Delicious' experiments only. Return bloom was measured in 1999 by calculating the percentage of flowering spurs from a sample of 100 spurs per limb on two randomly selected limbs per tree.

NAA \pm ETHEPHON, 20022003. Thirty-two uniform 'Fuji'/ M.7 trees were selected at a commercial orchard in Henderson County, N.C. The trees were blocked into eight replicates with four trees in each arranged as a randomized complete block design experiment. NAA ( 5 ppm, Fruitone N) and ethephon (150 ppm Ethrel; Bayer CropScience, Research Triangle Park, N.C.) were applied, either alone or in combination, to fully guarded single-tree plots with an axial fan airblast sprayer calibrated to deliver $80 \%$ of the calculated TRV or $175 \mathrm{gal} / \mathrm{acre}$. There was also an unsprayed control treatment. The three spray treatments were applied on 17 June, I July, 15 July, and 29 July. Return bloom was assessed in 2003 by calculating the percentage of flowering spurs from a sample of 50 spurs per limb on two randomly selected limbs per tree.

NAA \pm ETHEPHON, 20042005. The effects of a single application of 444 or $666 \mathrm{ppm}$ ethephon (equivalent to either 48 or $72 \mathrm{fl} \mathrm{oz}$ / acre Ethrel, respectively) and four applications of 5 ppm NAA (Fruitone $\mathrm{N})$ were compared in two commercial orchards ('Golden Delicious' / M.7 and 'Fuji'/M.7) in Henderson County, N.C., in 2004. An additional treatment combined a single application of 444 ppm ethephon with four applications of 5 ppm NAA. Ethephon was applied on 3 June (6 weeks after bloom); NAA was applied on 17 June, 30 June, 20 July, and 29 July. In addition, there was an untreated control treatment. The spray treatments were applied with an axial fan airblast sprayer calibrated to deliver $80 \%$ of the calculated TRV in each orchard or $200 \mathrm{gal} /$ acre to fully guarded singletree plots. Treatments were arranged in a randomized complete block design with five ('Fuji') or six ('Golden Delicious') replications. A random sample of 20 fruit per plot was removed at harvest of the 'Golden Delicious' trial only for assessment of treatment effects on fruit firmness (Effegi penetrometer, 11.1-mm tip). Return bloom was measured in 2005 by calculating the percentage of flowering spurs from a sample of 100 spurs per limb on two randomly selected limbs per tree.

Time of NAA application, 2004-2005. The effect of time of NAA application in 2004 on return bloom of 'Golden Delicious' / M.7 in 2005 was evaluated in a commercial orchard in Henderson County, N.C. The treatments were 1) an untreated control; 2) early summer 5 ppm NAA applications (as Fruitone $\mathrm{N}$ applied on 17 June, 30 June, 20 July, and 29 July); 3) preharvest 5 ppm NAA applications (applied on 16 Aug., 23 Aug., 3 Sept., and 13 Sept.); 4 ) postharvest 5 ppm NAA applications (applied on 21 Sept., 29 Sept., 10 Oct., and 21 Oct.); and 5 ) the combination of early summer and preharvest $5 \mathrm{ppm}$ NAA treatments (eight applications in total). The treatments were applied to fully guarded single-tree plots with an axial fan airblast sprayer calibrated to deliver $80 \%$ of the calculated TRV or $200 \mathrm{gal} /$ acre. The treatments were arranged in a randomized complete block design experiment with six replications. A random sample of 20 fruit per plot was removed at harvest for assessment of treatment effects on fruit firmness like in the previous experiments. Return bloom was measured in 2005 by calculating the percentage of flowering spurs from a sample of 100 spurs per limb on two randomly selected limbs per tree.

EFFECTS OF FLOWERING LEVEL ON THE ETHEPHON RESPONSE, 20042005. The effect of flower cluster density in the year of treatment on the return bloom response to ethephon was investigated in a commercial 'Golden Delicious' / M.7 orchard in Henderson County, N.C., in 2004. Twenty trees of uniform size were selected from within the orchard and divided into two groups, each with a similar range of flowering levels determined subjectively at bloom. The actual flowering level of each tree was determined by calculating the flower cluster density (no. of 
clusters $/ \mathrm{cm}^{2}$ ) from counts of the number of flower clusters and limb diameter measurements for two sample limbs on each tree. One group of trees received a single application of $444 \mathrm{ppm}$ ethephon on 3 June with an axial fan airblast sprayer calibrated to deliver $80 \%$ of the calculated TRV or $200 \mathrm{gal} / \mathrm{acre}$. The other group of trees was left untreated. Return bloom was calculated in 2005 as the percentage of floral spurs on each of the two sample limbs selected in the previous year.

NAA, ethephon, $\mathbf{G A}_{4+7}$, 2005-2006. Various early summer $\mathrm{NAA}$, ethephon, and $\mathrm{GA}_{4+7}$ treatments were applied to 'Cameo' / M.9 (M.9), 'Smoothee Golden Delicious'/M.9, and 'Mutsu'/M.7 trees in a commercial orchard in Blueridge, Ga., in 2005. Ethephon treatments were planned to compare the efficacy of $96 \mathrm{fl} \mathrm{oz} /$ acre Ethrel applied as either single or split applications. The treatments were 1) an untreated control; 2) 5 ppm NAA (Fruitone N) applied on 17 June, 30 June, 18 July, and 28 July; 3) 1267 ppm ethephon applied on June 17; 4) 634 ppm ethephon applied on 17 June and 18 July; 5) 316 ppm ethephon applied on 17 June, 30 June, 18 July, and 28 July; 6) 316 ppm ethephon plus 5 ppm NAA applied on 17 June, 30 June, 18 July, and 28 July; and 7) 316 ppm ethephon plus 15 ppm $\mathrm{GA}_{4+7}$ (Novagib; Fine Americas Inc., Walnut Creek, Calif.) applied on 17 June, 30 June, 18 July, and 28 July. The growth regulator treatments were applied to fully guarded single tree plots with an axial fan airblast sprayer calibrated to deliver $80 \%$ of the calculated TRV in each orchard or $140 \mathrm{gal} / \mathrm{acre}$. The treatments were applied to each cultivar in a randomized complete block design experiment with six replications. A random sample of 20 fruit per plot was removed at harvest for assessment of treatment effects on fruit firmness like in the previous experiments. Return bloom was measured by calculating the percentage of flowering spurs on two randomly selected limbs per tree in 2006.

Statistical analysis. Each experiment was analyzed as a randomized complete block design using the Generalized Linear Model (GLM) procedure of SAS (SAS Institute, Cary, N.C.). Mean separations were achieved using the Waller-Duncan k-ratio $t$ test. $P$ values from analysis of variance tables were included to indicate the level of significance for treatment effects. The flowering level/ethephon study was analyzed using regression procedures of SAS after it was determined that each level of ethephon had a different slope using the GLM procedure.

\section{Results and discussion}

EARLY SUMMER NAA TREATMENTS. Early summer applications of 5 ppm NAA resulted in an increase in the percentage of floral spurs in the year after treatment compared with the untreated control in nine of $10 \mathrm{ex}$ periments, but the increase was statistically significant in only six experiments at $P<0.05$. Early summer NAA treatments resulted in an additional $14 \%$ to $60 \%$ of spurs producing a flower compared with an untreated control, depending on the experiment. Early summer NAA sprays failed to increase return bloom of 'Fuji' in 2005 (only an additional $6 \%$ of spurs were floral; Table 1 ), 2 ), 'Cameo' in 2006 (an additional $7 \%$ of spurs were floral; Table 3 ), or 'Golden Delicious' in 2006 (3\% fewer spurs were floral; Table 3 ). In most instances in which early summer NAA sprays did not result in a significant increase in return bloom, the initial crop load in the year of treatment appeared to be excessive. In the 2004 'Fuji' experiment, the initial crop load in the year of treatment was high; an average of 417 fruit was removed per tree at the time of hand thinning to establish a commercial crop load. The cultivars used in the 2005 experiments did not receive chemical thinning treatments, although they were 'Golden Delicious' in 2005 (an additional $8 \%$ of spurs were floral; Table

hand thinned to a commercial crop load at the completion of natural fruit drop. The crop load of these three cultivars was excessive during the early part of the season, which might explain why early summer NAA treatments resulted in a significant increase in return bloom of only one of the three cultivars tested.

The response to the number of NAA applications was not consistent between cultivars, strains, or even years. Four early summer applications of 5 ppm NAA were required to increase return bloom of 'Delicious' in 1999 (Table 4), whereas a single application of $5 \mathrm{ppm}$ NAA increased return bloom of 'Smoothee Golden Delicious' in 1999 and additional applications did not increase return bloom further (Table 4). In the 1999 'Golden Delicious' experiment, however, there was a positive linear relationship between the number of NAA applications and return bloom (Table 4): percentage floral spurs in $1999=55.6+(7.6 \times$ number of NAA sprays in 1998), $\mathrm{R}^{2}=27.54$. These observations indicate that factors other than genetics can modify the return bloom response to NAA. The level of bloom or initial crop load in the year of treatment may be responsible, at least in part, for these inconsistencies.

Preharvest NAA treatments. Four preharvest applications of $5 \mathrm{ppm}$ NAA increased return bloom of 'Delicious' in 1999 and 'Golden Delicious' in 2005 compared with the untreated control in each experiment, resulting in an additional $60 \%$ and $15 \%$ of spurs producing a flower cluster, respectively (Tables 2 and 4 ). The level of return bloom was similar for preharvest and early summer NAA sprays in both experiments. Combining early summer NAA sprays

Table 1. Effects of ethephon and naphthaleneacetic acid (NAA) treatments in 2004 on bloom of 'Golden Delicious' and 'Fuji' apple trees in 2005.

\begin{tabular}{|c|c|c|}
\hline \multirow[b]{2}{*}{ Treatment } & \multicolumn{2}{|c|}{ Return bloom ${ }^{\mathrm{z}}$ (\% floral spurs) } \\
\hline & Golden Delicious & Fuji \\
\hline Control & $17 \mathrm{a}^{\mathrm{y}}$ & $19 a$ \\
\hline Ethephon $\left(1 \times 444 \mathrm{ppm}^{\mathrm{x}}\right)$ & $42 \mathrm{c}$ & $35 \mathrm{~b}$ \\
\hline Ethephon $\left(1 \times 666 \mathrm{ppm}^{\mathrm{w}}\right)$ & $41 \mathrm{c}$ & $29 \mathrm{ab}$ \\
\hline $\mathrm{NAA}(4 \times 5 \mathrm{ppm})$ & $35 \mathrm{bc}$ & $25 \mathrm{ab}$ \\
\hline Ethephon $\left(1 \times 444 \mathrm{ppm}^{\mathrm{x}}\right)+\mathrm{NAA}(4 \times 5 \mathrm{ppm})$ & $32 \mathrm{~b}$ & 18 a \\
\hline Significance & 0.003 & 0.04 \\
\hline
\end{tabular}


Table 2. Effects of time of four applications of $5 \mathrm{ppm}\left(\mathrm{mg} \cdot \mathrm{L}^{-1}\right)$ naphthaleneacetic acid (NAA) at different times in 2004 on bloom of 'Golden Delicious' apple trees in 2005.

\begin{tabular}{lc} 
Treatment & $\begin{array}{c}\text { Return bloom } \\
\text { (\% floral spurs) }\end{array}$ \\
\hline Control & $12 \mathrm{a}^{\mathrm{y}}$ \\
Early summer $^{\mathrm{x}} \mathrm{NAA}$ & $20 \mathrm{abc}$ \\
Preharvest $^{\mathrm{w}} \mathrm{NAA}$ & $27 \mathrm{c}$ \\
Early summer NAA + preharvest NAA $^{\mathrm{b}}$ & $24 \mathrm{bc}$ \\
Postharvest $^{\mathrm{v}}$ NAA & $18 \mathrm{ab}$ \\
Significance & 0.10 \\
\hline
\end{tabular}

${ }^{z}$ Return bloom was assessed on 100 spurs on each of two randomly selected limbs per tree.

y Mean separation within columns by the Waller-Duncan k-ratio $t$ test.

${ }^{x}$ Early summer treatment refers to four biweekly applications, two in June and two in July.

wreharvest treatment refers to four weekly applications beginning 1 month before anticipated harvest.

"Postharvest treatments refers to four weekly applications beginning 1 week after harvest.

with preharvest NAA sprays did not result in any additional increase in return bloom compared with either early summer or preharvest NAA sprays alone (Tables 2 and 4 ).

Early summer and preharvest NAA sprays were applied during the intervals from $\approx 60$ to $90 \mathrm{~d}$ or 120 to $150 \mathrm{~d}$ after bloom, respectively. The time when developing apple buds become committed to floral development, as indicated by doming of the apical meristem of the bud, is influenced by many factors, including the time of cessation of shoot growth, crop load, year, and cultivar (Buban and Faust, 1982; Hoover et al., 2004; McArtney et al., 2001). In general, however, doming within spur buds

occurs during the period from 60 to $150 \mathrm{~d}$ after bloom (Hirst and Ferree, 1995; Hoover et al., 2004; McArtney et al., 2001; McLaughlin and Greene, 1991). Therefore, early summer NAA sprays were applied between the period of onset and maximum observance of doming at the apical meristem. However, preharvest NAA sprays increased the proportion of floral spurs in the year after treatment, although they were probably applied after the completion of doming in spur buds. Late summer differentiation of flower buds has been observed on nonbearing trees (Tromp, 1968) and is observed in certain years, cultivars, or areas where the growing period is long (Buban and Faust,

Table 3. Effects of early summer naphthaleneacetic acid (NAA), ethephon, and gibberellin A4 + A7 $\left(\mathrm{GA}_{4+7}\right)$ treatments in 2005 on the percentage floral spurs of 'Cameo', 'Mutsu', and 'Golden Delicious' apple trees in 2006.

\begin{tabular}{|c|c|c|c|}
\hline \multirow[b]{2}{*}{ Treatment } & \multicolumn{3}{|c|}{$\begin{array}{l}\text { Return bloom } \\
\text { (\% floral spurs) }\end{array}$} \\
\hline & Cameo & Mutsu & $\begin{array}{c}\text { Golden } \\
\text { Delicious } \\
\end{array}$ \\
\hline Control & $6 d^{x}$ & $15 \mathrm{c}$ & 26 \\
\hline Early summer ${ }^{w}$ NAA $(4 \times 5$ ppm $)$ & $13 \mathrm{bcd}$ & $55 \mathrm{a}$ & 23 \\
\hline $\begin{array}{l}\text { Early summer } \\
\quad \text { ethephon }\left(4 \times 316 \mathrm{ppm}^{\mathrm{v}}\right)\end{array}$ & $20 \mathrm{~b}$ & $25 \mathrm{bc}$ & 36 \\
\hline $\begin{array}{l}\text { Early summer } \\
\quad \text { ethephon }\left(2 \times 634 \mathrm{ppm}^{\mathrm{u}}\right)\end{array}$ & $7 \mathrm{~cd}$ & $29 \mathrm{bc}$ & 43 \\
\hline $\begin{array}{l}\text { Early summer } \\
\quad \text { ethephon }\left(1 \times 1268 \mathrm{ppm}^{\mathrm{t}}\right)\end{array}$ & $15 \mathrm{bcd}$ & $24 \mathrm{bc}$ & 46 \\
\hline $\begin{array}{l}\text { Early summer NAA }(4 \times 5 \mathrm{ppm})+\text { ethephon } \\
\quad(4 \times 316 \mathrm{ppm})\end{array}$ & $19 \mathrm{bc}$ & $15 \mathrm{c}$ & 52 \\
\hline $\begin{array}{l}\text { Early summer ethephon }(4 \times 316 \mathrm{ppm})+\mathrm{GA}_{4+7} \\
\quad(4 \times 15 \mathrm{ppm})\end{array}$ & $50 \mathrm{a}$ & $32 \mathrm{~b}$ & 32 \\
\hline Significance & 0.003 & 0.04 & 0.79 \\
\hline
\end{tabular}

${ }^{\mathrm{z}}$ Early summer treatment refers to four biweekly applications, two in June and two in July.

${ }^{y}$ Return bloom was assessed on 100 spurs on each of two randomly selected limbs per tree.

${ }^{\mathrm{x}}$ Mean separation within columns by the Waller-Duncan k-ratio $t$ test.

"Early summer treatment refers to four biweekly applications, two in June and two in July.

${ }^{v} 1 \mathrm{ppm}=1 \mathrm{mg} \cdot \mathrm{L}^{-1}, 316 \mathrm{ppm}$ ethephon is equivalent to $24 \mathrm{fl} \mathrm{oz} /$ acre $\left(1.75 \mathrm{~L} \cdot \mathrm{ha}^{-1}\right)$ Ethrel (Bayer CropScience, Research Triangle Park, N.C.).

"634 ppm ethephon is equivalent to $48 \mathrm{fl} \mathrm{oz} /$ acre $\left(3.5 \mathrm{l} \mathrm{L} \cdot \mathrm{ha}^{-1}\right)$ Ethrel.

${ }^{\mathrm{t}} 1268 \mathrm{ppm}$ ethephon is equivalent to $96 \mathrm{fl} \mathrm{oz} /$ acre $\left(7.02 \mathrm{~L} \cdot \mathrm{ha}^{-1}\right)$ Ethrel.
1982). Clearly, preharvest NAA sprays extended the period of floral commitment into late summer in the present studies. This response may be peculiar to the southeastern U.S., where shoot growth typically continues over a long period.

ETHEPHON. Four applications of $150 \mathrm{ppm}$ ethephon to 'Fuji' trees in 2002 , equivalent to a total of $112 \mathrm{fl}$ $\mathrm{oz} /$ acre Ethrel, resulted in a significant increase in return bloom compared with an untreated control. Early summer ethephon sprays increased return bloom of 'Fuji' in 2002 as effectively as early summer NAA sprays (Table 5 ). A single application of 444 ppm ethephon to 'Golden Delicious' and 'Fuji' trees in 2004 resulted in $25 \%$ and $16 \%$ more floral spurs in the year after treatment compared with the control treatment in each experiment, respectively (Table 1). Ethephon at 666 ppm promoted return bloom of 'Golden Delicious' in 2005 as effectively as 444 ppm ethephon, whereas return bloom of 'Fuji'/M7 was only promoted at the lower rate of ethephon. Return bloom of 'Mutsu' and 'Golden Delicious' were unaffected by ethephon treatments in 2005 , although four applications of 316 ppm ethephon increased return bloom of 'Cameo' (Table 3). Although trees of all three cultivars had a heavy bloom in 2005, none were chemically thinned so that the initial crop load was high. Although they were hand thinned to a commercial crop load at the completion of natural fruit drop in June, the lack of response to ethephon treatments in 2005 may have been the result of the heavy crop load during the early part of the season. There were no visual effects of the ethephon treatments on crop load in any of the studies reported here, although crop load itself was not measured.

GrowTH REgulator COMBINATIONS. Combining early summer ethephon and NAA sprays in 2002 resulted in an additive effect on return bloom of 'Fuji' in 2003 compared with applications of either growth regulator alone (Table 5 ). In the 2004 studies with 'Golden Delicious' and 'Fuji', however, a single application of ethephon followed by four applications of NAA resulted in significantly fewer floral spurs in the year after treatment compared with 
Table 4. Effects of frequency of $5 \mathrm{ppm}\left(\mathrm{mg} \cdot \mathrm{L}^{-1}\right)$ naphthaleneacetic acid (NAA) sprays in 1998 on bloom of 'Delicious' and 'Golden Delicious' apple trees in 1999.

\begin{tabular}{lccc}
\hline & \multicolumn{3}{c}{ Return bloom $^{\mathrm{z}}$ (\% floral spurs) } \\
\cline { 2 - 4 } Treatment & Delicious & $\begin{array}{c}\text { Smoothee Golden } \\
\text { Delicious }\end{array}$ & $\begin{array}{c}\text { Golden } \\
\text { Delicious }\end{array}$ \\
\hline Control & $21 \mathrm{a}^{\mathrm{y}}$ & $56 \mathrm{a}$ & 54 \\
1 early summer ${ }^{\mathrm{x}}$ application & $34 \mathrm{a}$ & $83 \mathrm{~b}$ & 61 \\
2 early summer applications & $26 \mathrm{a}$ & $89 \mathrm{~b}$ & 77 \\
3 early summer applications & $30 \mathrm{a}$ & $88 \mathrm{~b}$ & 79 \\
4 early summer applications & $75 \mathrm{~b}$ & $86 \mathrm{~b}$ & 83 \\
4 applications (preharvest) & $81 \mathrm{~b}$ & - & - \\
8 applications & $85 \mathrm{~b}$ & - & 0.23 \\
$\quad$ (early summer + preharvest & & - \\
Significance & $<0.0001$ & $<0.0001$ & $\mathrm{~L}^{*}$ \\
Linear regression & $\mathrm{NS}$ & $\mathrm{NS}$ &
\end{tabular}

${ }^{2}$ Return bloom was assessed on 100 spurs on each of two randomly selected limbs per tree.

${ }^{y}$ Mean separation within columns by the Waller-Duncan k-ratio $t$ test.

xEarly summer sprays were applied biweekly beginning in mid-June.

wPreharvest applications refers to four weekly applications beginning 1 month before anticipated harvest.

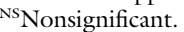

ethephon treatment alone (Table 1 ). The effects of ethephon and NAA on return bloom of 'Fuji' were additive in the 2002 study, in which ethephon was tank mixed with NAA and applied $\approx 8,10,12$, and 14 weeks after bloom (Table 5), whereas NAA sprays applied $8,10,12$, and 14 weeks after bloom in 2004 reduced the efficacy of a single ethephon application 6 weeks after bloom (Table 1). Differences in growth regulator concentration, time of application, tree vigor, or initial crop load between these different studies may have influenced the return bloom response. Combining 15 ppm $\mathrm{GA}_{4+7}$ with each early summer ethephon treatment significantly increased return bloom of 'Cameo' compared with ethephon alone, but did not influence return bloom of 'Mutsu' or 'Golden Delicious' (Table 3). The basis for these inconsistent responses between cultivars is not known at this time.

Table 5. Effects of four early summer applications of $150 \mathrm{ppm}\left(\mathrm{mg} \cdot \mathrm{L}^{-1}\right)$ ethephon and $5 \mathrm{ppm}$ naphthaleneacetic acid (NAA) in 2002, alone or in combination, on bloom of 'Fuji' apple trees in 2003.

\begin{tabular}{lc}
\hline Treatment & $\begin{array}{c}\text { Return bloom } \\
\text { (\% floral spurs) }\end{array}$ \\
\hline Control & $26 \mathrm{a}^{\mathrm{y}}$ \\
Ethephon & $41 \mathrm{~b}$ \\
NAA & $40 \mathrm{~b}$ \\
Ethephon + NAA & $58 \mathrm{c}$ \\
Significance & 0.0003 \\
\hline
\end{tabular}

${ }^{2}$ Return bloom was assessed on 50 spurs on each of two randomly selected limbs per tree.

Mean separation within columns by the WallerDuncan k-ratio $t$ test.
LEVEL OF BLOOM AND THE ETHEPHON RESPONSE. There was a negative linear relationship between flower cluster density in 2004 and return bloom of 'Golden Delicious' (Fig. 1). Furthermore, there was a significant interaction between the effects of ethephon and flower cluster density on return bloom $(P=$ 0.0009 ), indicating the slope of this relationship was significantly different for each level of ethehpon ( 0 or 444 on control trees in 2005 was decreased by $9 \%$ for each unit increase in flower cluster density (flowers $/ \mathrm{cm}^{2}$ branch cross-sectional area) in 2004 , whereas this decrease was only $2 \%$ in trees treated with ethephon. This analysis indicates that the relative efficacy of ethephon as a return bloom stimulant was increased with increasing flower cluster density in the year of treatment. These results conflict with the lack of responses that were observed after ethephon treatments in 2005 (Table 3); however, the responses may be explained by differences in initial crop load. Trees in the 2005 experiments did not receive chemical thinning sprays and therefore had heavy initial crop loads, at least until the time they were hand thinned in June. On the other hand, chemical thinners were applied to trees in the 2004 'Golden Delicious' study so that even trees with a high flower cluster density would have presumably had a lighter initial crop load than trees in the 2005 experiments. Trees with a higher initial crop load will have greater numbers of seeds per tree and per spur. According to the $\mathrm{ppm})$. The proportion of floral spurs

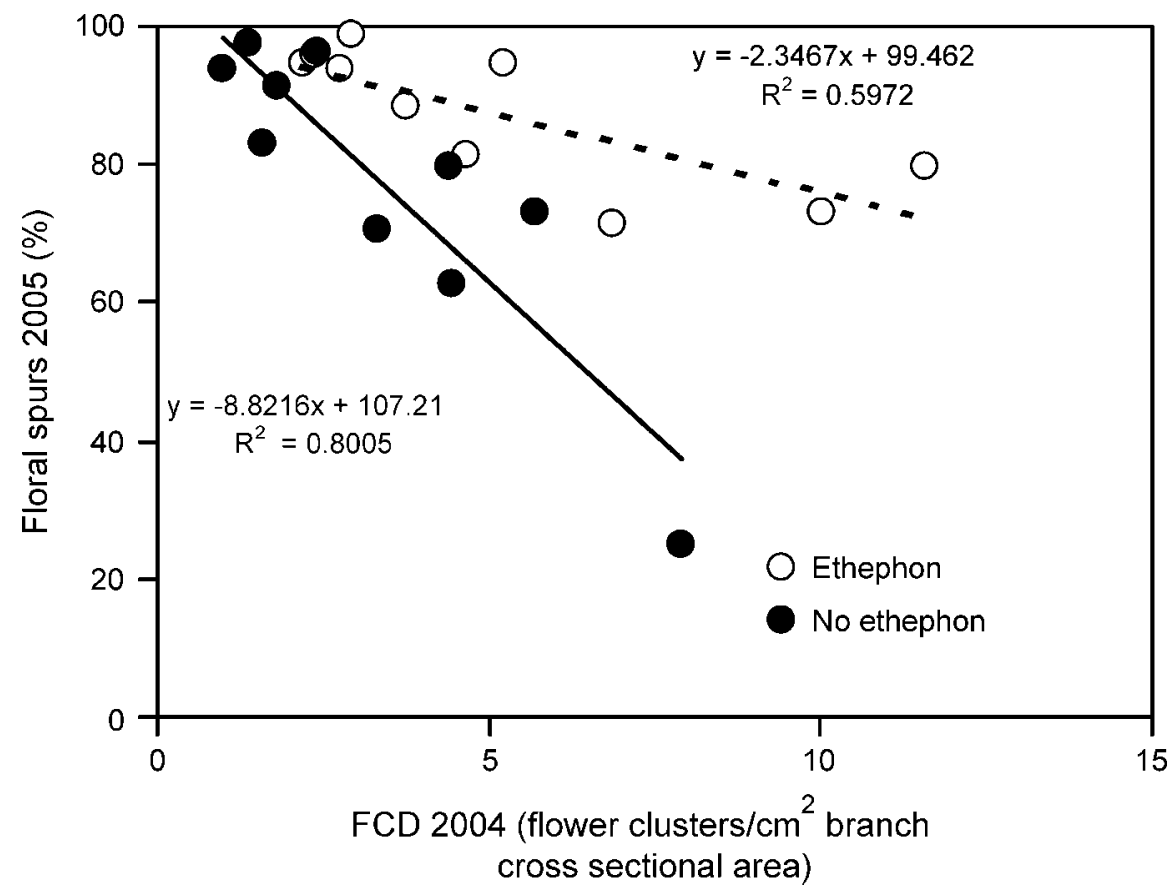

Fig. 1. Effects of flower cluster density (FCD) and $444 \mathrm{ppm}\left(\mathrm{mg} \cdot \mathrm{L}^{-1}\right)$ ethephon [equivalent to $48 \mathrm{fl} \mathrm{oz} /$ acre $\left(3.51 \mathrm{~L} \cdot \mathrm{ha}^{-1}\right.$ ) Ethrel (Bayer CropScience, Research Triangle Park, N.C.) in 2004 on bloom of 'Golden Delicious' apple trees in 2005 measured as the percentage of floral spurs. Data points are individual tree averages based on the same two sample limbs per tree in each year. 
Table 6. Effects of biweekly applications of naphthaleneacetic acid (NAA) and ethephon beginning in mid-June on flesh firmness in the year of treatment.

\begin{tabular}{|c|c|c|c|c|c|c|}
\hline \multirow[b]{3}{*}{ Treatment } & \multicolumn{6}{|c|}{ Flesh firmness $(\mathrm{lbf})^{\mathrm{z}}$} \\
\hline & \multicolumn{2}{|c|}{1998} & \multirow{2}{*}{$\begin{array}{c}2004 \\
\text { Golden } \\
\text { Delicious }\end{array}$} & \multicolumn{3}{|c|}{2005} \\
\hline & Golden Delicious & $\begin{array}{c}\text { Smoothee Golden } \\
\text { Delicious }\end{array}$ & & Cameo & Mutsu & $\begin{array}{c}\text { Golden } \\
\text { Delicious } \\
\end{array}$ \\
\hline Control & $15.8 \mathrm{ab}^{\mathrm{y}}$ & $15.4 \mathrm{ab}$ & $15.3 \mathrm{ab}$ & 15.0 & $16.4 \mathrm{a}$ & 14.5 \\
\hline $1 \times 5 \mathrm{ppm}^{\mathrm{x}} \mathrm{NAA}$ & $15.9 \mathrm{a}$ & $14.8 \mathrm{c}$ & - & - & - & - \\
\hline $2 \times 5$ ppm NAA & $14.9 \mathrm{~d}$ & $15.6 \mathrm{a}$ & - & - & - & - \\
\hline $1 \times 444$ ppm ethephon & - & - & $15.3 \mathrm{ab}$ & - & - & - \\
\hline $1 \times 666$ ppm ethephon & - & - & $15.0 \mathrm{c}$ & - & - & - \\
\hline $4 \times 5$ ppm NAA $+1 \times 444$ ppm ethephon & - & - & $15.1 \mathrm{bc}$ & & & \\
\hline $4 \times 5$ ppm NAA $+4 \times 316$ ppm ethephon & & & & 14.6 & $15.6 \mathrm{~b}$ & 15.2 \\
\hline $4 \times 316$ ppm ethephon & - & - & - & 14.4 & $15.6 \mathrm{~b}$ & 14.5 \\
\hline $2 \times 634$ ppm ethephon & - & - & - & 14.7 & $16.3 \mathrm{a}$ & 15.1 \\
\hline
\end{tabular}

${ }^{\mathrm{z}} \mathrm{l} \mathrm{lbf}=4.4482 \mathrm{~N}$.

yean separation within columns by the Waller-Duncan k-ratio $t$ test.

${ }^{x} \mathrm{l} \mathrm{ppm}=\mathrm{l} \mathrm{mg} \cdot \mathrm{L}^{-1}$.

hypothesis first proposed by Chan and Cain (1967), it is a hormonal signal derived from the developing seeds that inhibits flower bud formation in the adjacent spur tissues. These results suggest that a successful chemical thinning program must be combined with ethephon treatment(s) to ensure adequate return bloom of strongly biennial apple cultivars.

Flesh FIRMness. The effects of growth regulator treatments on flesh firmness at harvest were not consistent (Table 6). Flesh firmness at harvest was reduced by an early summer NAA program $(4 \times 5 \mathrm{ppm})$ compared with the control in three of six experiments (0.4-1.0 lbf reduction, depending on the experiment) or had no effect at all. Early summer ethephon sprays $(4 \times 316 \mathrm{ppm})$ reduced flesh firmness of 'Mutsu' by $0.8 \mathrm{lbf}$ but had no effect on firmness of 'Cameo' or 'Golden Delicious'. There was a trend for split applications of ethephon in 2005 to have a more negative effect on flesh firmness than a single application at a higher rate, although the same total amount was applied per acre. Reductions in flesh firmness were typically associated with reduced starch content (data not shown) indicating that these treatments advanced fruit maturity.

\section{Conclusions}

Application of NAA or ethephon in the heavy cropping year of a biennial bearing cycle generally increased bloom of apple in the year after treatment. However, they were not effective in situations in which the initial crop load was high. In general, a single application of ethephon was as effective as four applications of NAA in promoting return bloom. The timing of multiple NAA applications was not critical; four biweekly applications during June and July promoted return bloom as effectively as four weekly applications leading up to harvest. The positive effects of preharvest NAA applications on return bloom suggest that NAA may prolong the period of flower bud differentiation in apple. NAA or ethephon treatments for return bloom reduced flesh firmness at harvest by up to $1 \mathrm{lbf}$, although this response was not observed in all experiments. The combination of NAA and ethephon did not consistently increase return bloom compared with either growth regulator alone, although their effects were additive in one experiment. An effective chemical thinning program and either early summer NAA or ethephon sprays both appear to be prerequisites for achieving more consistent cropping of strongly biennial apple cultivars.

\section{Literature cited}

Bertelsen, M.G. and D.S. Tustin. 2002. Suppression of flower bud formation in light cropping trees of 'Pacific Rose' apple using gibberellin sprays. J. Hort. Sci. Biotechnol. 77:753-757.
Buban, T. and M. Faust. 1982. Flower bud induction in apple trees: Internal control and differentiation. Hort. Rev. (Amer. Soc. Hort. Sci.) 4:174-203.

Chan, B.C. and J.C. Cain. 1967. The effect of seed formation on subsequent flowering in apple. Proc. Amer. Soc. Hort. Sci. 91:63-67.

Dennis, F.G., Jr. and L.J. Edgerton. 1966. Effects of gibberellins and ringing upon apple fruit development and flower bud formation. Proc. Amer. Soc. Hort. Sci. 88:14-24

Ferguson, I.B. and C.B. Watkins. 1992. Crop load affects mineral concentrations and incidence of bitter pit in 'Cox's Orange Pippin' apple fruit. J. Amer. Soc. Hort. Sci. 117:373-376.

Ferree, D.C. and J.C. Schmid. 2000. Chemical thinning 'Fuji' apple in the Midwest. J. Amer. Pomol. Soc. 54:61-67.

Guak, S., M. Beulah, and N.E. Looney. 2004. Auxinic blossom thinners (MCPBethyl and NAA) inhibit return flowering on Fuji/M.26 apple trees. Acta Hort. 653:87-91.

Harley, C.P., H.H. Moon, and L.O. Regeimbal. 1958. Evidence that postbloom apple thinning sprays of naphthaleneacetic acid increase blossom bud formation. Proc. Amer. Soc. Hort. Sci. $72: 52-56$

Hirst, P.M. and D.C. Ferree. 1995. Rootstock effects on the flowering of 'Delicious' apple. I. Bud development. J. Amer. Soc. Hort. Sci. 120:1010-1017.

Hoover, E., N. De Silva, S. McArtney, and P. Hirst. 2004. Bud development and floral morphogenesis in four apple 


\section{Research Reports}

cultivars. J. Hort. Sci. Biotechnol. 79: 981-984.

Jonkers, H. 1979. Biennial bearing in apple and pear: A literature survey. Scientia Hort. 11:303-317.

Li, S.H., Z.Q. Meng, T.H. Li, H.Z. Liu, and Y.C. Tu. 1995. Critical period of flower bud induction in 'Red Fuji' and 'Ralls Janet' apple trees. Gartenbauwissenschaft 60:240-245.

Looney, N.E., R.P. Pharis, and M. Noma. 1985. Promotion of flowering in apple trees with gibberellin A4 and C-3 epigibberellin A4. Planta 165:292-294.

Marino, F. and D.W. Greene. 1981. Involvement of gibberellins in the biennial bearing of 'Early McIntosh' apples. J. Amer. Soc. Hort. Sci. 106:593596.

McArtney, S.J. 1994. Exogenous gibberellin affects biennial bearing and the fruit shape of 'Braeburn' apple. N.Z.J. Crop Hort. Sci. 22:343-346.

McArtney, S.J., E.E. Hoover, P.M. Hirst, and I.R. Brooking. 2001. Seasonal variation in the onset and duration of flower development in 'Royal Gala' apple. J. Hort. Sci. Biotechnol. 76:536-540.
McArtney, S.J. and S.H. Li. 1998. Selective inhibition of flowering on 'Braeburn' apple trees with gibberellins. HortScience 33:699-700.

McLaughlin, J.W. and D.W. Greene. 1991. Fruit and hormones influence flowering of apple. I. Effect of cultivar. J. Amer. Soc. Hort. Sci. 1 16:446-449.

Meador, D.B. and B.H. Taylor. 1987. Effect of early season foliar sprays of GA4/7 on russeting and return bloom of 'Golden Delicious' apple. HortScience 22:412-415.

Meland, M. 1998. Thinning apples and pears in a Nordic climate. III. The effect of NAA, ethephon and lime sulfur on fruit set, yield and return bloom of three apple cultivars. Acta Hort. 463:517-525.

Reginato, M.G., G.F. Esguep, and R.R. Callejas. 2001. Evaluation of chemical thinning treatments on 'Braeburn' apple trees. Agricultura Tecnica 61:401-412.

Schwallier, P. 2006. Integrated pest management resources. 5 Sept. $2006<w w w . i p m . m s u . e d u / c a t 06$ fruit/ f06-06-06.htm>
Tromp, J. 1968. Flower-bud formation and shoot growth in apple as affected by shoot orientation. Acta Botanica Neerlandica 17:212-220.

Tromp, J. 1973. The interaction of growth regulators and tree orientation on fruit-bud formation. Acta Hort. 34:185-188.

Tromp, J. 1982. Flower bud formation in apple as affected by various gibberellins. J. Hort. Sci. 57:277-282.

UMass Fruit Team. 2001. Healthy fruit. 5 Sept. 2006. <http://www.umass.edu/ fruitadvisor/healthy_fruit/hfl 101.htm >.

UMass Fruit Team, 2002. Healthy fruit. 5 Sept. 2006. <http://www.umass.edu/ fruitadvisor/healthy_fruit/hfl202.pdf>.

Williams, M.W. 1972. Induction of spur and flower bud formation in young apple trees with chemical growth retardants. J. Amer. Soc. Hort. Sci. 97:210-212.

Williams, M.W. 1979. Chemical thinning of apples. Hort. Rev. (Amer. Soc. Hort. Sci.) 1:270-300. 